\title{
コンクリートの種類が CFT の INFLUENCE OF TYPE OF CONCRETE 圧入高さに及ぼす影響について ON INJECTION HEIGHT OF CFT
}

\author{
岩沢 徹—*1 \\ 高野 㹂—* $*$ - \\ キーワード \\ コンクリート充塤鋼管, 水セメント比, 調合, 充穓性, タイアアラム, 圧入高 \\ さ \\ Keywords : \\ Concrete filled square hollow section column, Water-cement ratio, Mix \\ proportion, filling Capability, Opening area of diaphragm, Pushing up
}

Tetsu IWASAWA - *1
Torao KEMI - -3
Hajime TAKANO - *5

\author{
Yoshihisa NAKATA - *2 \\ Akio KAWANO $-* 4$
}

This paper deals with filling capabilities of concretes injected into CFT columns. Bibliographies related to current CFT injection technologies were widely reviewed and the filling capability was analyzed. Based on this background, normal and high-fluidity concretes were injected into two types of steel tubular columns, and effects of the type of concrete on the injection height in the steel columns were studied. The filling capability of concretes became more satisfactory when the high-fluidity concrete was used at a low water-cement ratio, and greatly influenced by the opening area of diaphragm with respect to the cross section of the steel columns.

\section{1。まえがき}

近年、コンクリート充填鋼管柱（以下、本報告ではCFTと呼ぶ） は、構造性能, 耐火性能および施工性の合理化などのメリットから 高層建築の新しい構造として注目を浴びている。このCFTは、鋼管 内にコンクリートを充填した構造であり、構造設計の要求性能に よって異なるが、コンクリートが鋼管内に十分に充填されなければ ならない。また、CFTへのコンクリート充填技術は、高流動コンク リートの開発によりめざましく進歩してきている。一般的に、CFT へのコンクリートの充填方法は、鋼管柱の下部に充填口を設け、コ ンクリートポンプにより压入する方法が採用されている。しかし、 鐥管柱内の柱梁接合部においてダイアフラムが存在するため、コン クリートが硬化したときに、ダイアフラムの下面に空隙が発生する 可能性を生じる。したがって、鋼管柱内に充填するコンクリート は、ポンプ压送性, 分離低減性および圧入性等の性能が要求され る。このCFTへのコンクリート充填性の向上は、施工方法の面から コンクリートの品質を向上させることおよびダイアフラムの開口面 積を大きくすることがあげられる。このCFTの構造酎力は、ダイア フラムの開口面積が大きくなるほど柱梁接合部における耐力の低下 につながる1）。ダイアフラムの開口面積が大きい場合は、必要な 耐力を確保するために、ダイアフラムの板厚を厚くする、外ダイア フラムを設けるなどの対応をとる必要がある。

現在、「C F T 構造技術指針・同解説」2）（以下、技術指針と呼 ぶ）では、柱断面積に対するダイアフラムの開口面積率を $15 \%$ 以上 にするように定められており、ダイアフラムの開口面積率を大きく することにより、充填性ならびに施工性を向上させているのが現状

\footnotetext{
*1 西松建設東京建築支店

（宁105-0001 港区虎)門1-20-10)

*2 西松建設東京建設支店 工修

*3 足利工業大学工学部建築学科 教授. 工博

*4 熊本工業大学工学部建築学科 教授·工博

*5 山宗化学技術部
}

である。このCFTへのコンクリートの充填技術におけるコンクリー トの調合、ダイアフラムの開口面積，高流動コンクリートの充填性 および鋼管柱の圧入高さの関係等については個々の実験研究は多い ものの、これらの条件を踏まえた一連の研究はなされていない。

そこで、本報告は、CFTへのコンクリートの充填技術として水セ メント比の異なるコンクリートが鋼管圧入高さに及は寸影響を明ら かにするために圧入施工実験を行ったものである。ここでは、柱断 面積に対するダイアフラムの開口面積率を $10 \%$ とし、高さ $12 \mathrm{~m}$ の鋼 管柱に高流動コンクリートと普通コンクリートとを用いて压入施工 実験を行い、コンクリートの種類が鋼管圧入高さに及ほす影響につ いてコンクリートの性状、充填性等の考慮を加えながら検討したも のである。

\section{2. 既往の研究と本研究との関係}

CFTコンクリート充填技術の現状を把握するために、ポンプ圧入 施工実験に関するCFTの文献調査を行った。文献調查の対象範囲は、 1989 1996年における日本建築学会大会学術講演会梗概集, コンク リート工学年次論文報告集, 建築技術拈よび各建設会社技術研究所 報において発表されたCFT の圧入に関する文献 (59 件3)，4））上 り、公表されたデー夕を用いた。既往の研究におけるCFTへのコン クリート充填技術を(1)鋼管寸法とダイアフラムの開口面積の関係, (2)ダイアフラムの開口面積率とダイアフラムの開口面積の関係(3)ダ イアフラムの開口面積率と鋼管圧入高さの関係, (4)ダイアフラムの 開口面積率と鋼管圧入高さの関係㧍よび(5)水セメント比と鋼管圧入 高さの関係の 5 項目について調查した。

*1 Nishimatsu Construction Co., Ltd. Tokyo Construction Branch

*2 Nishimatsu Construction Co., Ltd. Tokyo Construction Branch, M. Eng.

*3 Prof., Dept. of Architecture, Faculty Engineering, Ashikaga Institute of Technology, Dr. Eng.

*4 Prof., Dept. of Architecture, Faculty Engineering, Kumamoto Institute of Technology, Dr. Eng.

*5 Yamasou Chemical Co., Ltd. Technical Department 
（1）鋼管幅とダイアフラムの開口面積の関保（図 1）

既往の研究について実施工と模擬柱の実験に分類した。なお、図 中の曲線は、ダイアフラムの開口面積率を示す。実施工は、鋼管幅 $50 \sim 60 \mathrm{~cm}$ に対してダイアフラムの開口面積400〜 500 $\mathrm{cm}$ がが多く、ほと んどがダイアフラムの開口面積率 $15 \%$ 以上で行われていた。模擬柱 は、幅広く実験が行われていた。

（2）ダイアフラムの開口面積率と開口面積の関係（図 2)

模擬柱のダイアフラムの開口面積率とダイアフラムの開口面積の 関係は、ダイアフラムの開ロ面積が増加してもダイアフラムの開口 面積率がそれほど上昇しないものと、ダイアフラムの開口面積の増 加より、ダイアフラムの開口面積率の增加が大きいものとに分けら れる。前者は、鋼管幅の増加に併せてダイアフラムの開口面積を増 加させており、図中の勾配の急なラインで示すことができる。後者 は、鋼管幅に併せてダイアフラムの開口面積を決定するのではな く、充填性および施工性を重視したダイアフラムの開口面積を採用 しており、図中の勾配の緩いラインで示すことができる。したがっ て、実施工は、下のラインに近いことから、充填性および施工性を 重視していることが示唆される。

(3) ダイアフラムの開口面積率と鋼管圧入高さの関伯（図 3)

ダイアフラムの開口面積率は、技術指針で述べられている $15 \%$ 前 後で行われていた。鋼管圧入高さとダイアフラムの開口面積率に密 接な関係は見られなかったが、これはコンクリート調合にも関係し ているためと思われる。また、この中で模擬柱の実験で検証した後 に、実施工ではダイアフラムの開口面積率を上げている文献もみら れた。

（4）スラプフローと鋼管压入高さの関倸（図 4)

CFTの圧入実験は、ほとんどがスランプフロー $50 \mathrm{~cm}$ 以上の高流動 コンクリートで行われており、特に実施工では 9 割以上が高流動コ ンクリートであった。模擬柱は、普通コンクリートおよび高流動コ ンクリートで、スランブフローの実験が幅広く行われていた。ま た、鋼管圧入高さは、実施工では $15 \mathrm{~m}$ 以上で行われており、鋼管圧 入高さ20 40mが標準的な 1 回に圧入される高さであり、最大 $60 \mathrm{~m}$ まで压入された報告もあった。模擬柱では、圧入高さ $12 \mathrm{~m}$ 以下で、
ほとんどが5 m以下であった。鋼管圧入後のスランプフローの低下 は、実施工で大きく変化し、圧入高さによる影響と考えられる。

（5）水セメント比と鋼管圧入高さの関係（図 5 )

実施工での水セメント比は、30 40\%で行われて扔り、高強度コ ンクリートのものが多く見られ、模擬柱では水セメント比が幅広く 検討されていた。実施工で鋼管圧入高さによる水セメント比の変化 が30〜40\%とあまり変化させていないのは、充填性を重視している ためと考えられる。また、压入高さに関わらず、水セメント比に変 化がないことから実際に必要とされているコンクリート設計基準強 度より高くなる調合で行っていると考えられる。

以上の調査結果より、CFT柱へのコンクリート充填技術は、ダイ アフラムの開口面積 (率)，コンクリートのスランプフローおよび 水セメント比から充填性抢よび施工性を重視している傾向が見られ た。しかし、これらの要因が鋼管圧入に及ほす影響についての一連 の研究は行われていない。そこで、本研究は、水セメント比の異な るコンクリートを用いて圧入施工実験を行い、圧入高さへの影響を 調べた。

\section{3. 実験概要}

本実験は、水セメント比の異なるコンクリートがCFT柱の圧入高 さに及ほす影響として、压入高さのほかに(1)ポンプ压送・圧入によ るコンクリート品質变化, (2)コンクリート圧縮強度抢よび(3)コンク リートの充填状況の 3 項目について調べた5)。

3 . 1 実験計画

(1) 実験変数

実験変数を表 1 に示す。鋼管柱は、合計で 8 体で、これらは 2 種 類の鋼管断面を有する。コンクリートの吐出量は、 $10,30 \mathrm{~m}^{3} / \mathrm{h}$ の 2 種類を設定し、水平換算の配管距離を実長約 $120 \mathrm{~m}$ とした。

実験変数と試験体の関係を図 6 に、試験体の名称は実験变数を用 いて図 7 に示す規則に従う。

(2) コンクリート調合

コンクリートの調合は、高炉セメントB種を用いてブリーディン グ量 $0 \mathrm{~cm}^{3} / \mathrm{cm}^{2}$ 目標とした普通コンクリート（設計基準強度 $27 \mathrm{~N} /$

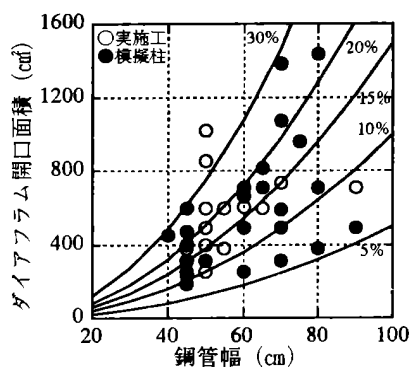

図 1 鋼管幅一 ダ仍フラム開口面積

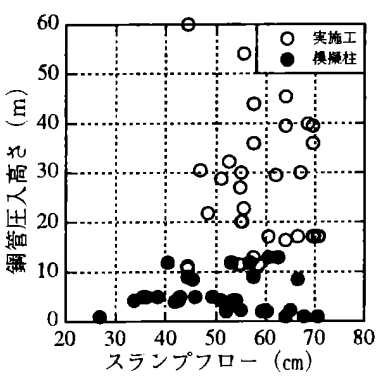

図 4 スランプフロ一

鋼管圧入高さ

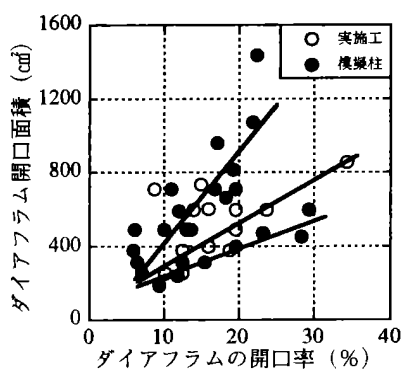

図 2 ダ仍フラム開口率— ダ仍フラム開口面積

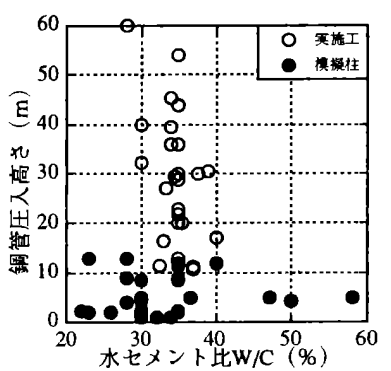

図 5 水七メ比一 鋼管圧入高さ

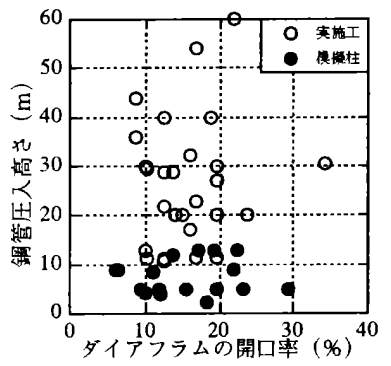

図 3 ダ仍7ラム開口率— 鋼管圧入高さ

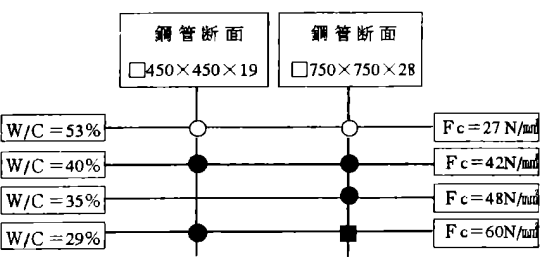

但し○；スランプ $21 \pm 1.5 \mathrm{~cm}, \bigcirc ;$ スランプフロ $60 \pm 5 \mathrm{~cm}$ ; スランプ 7ロ- $60 \pm 5 \mathrm{~cm}$ と $70 \pm 5 \mathrm{~cm}$ を目標

図6 実験変数と試験体

表 1 実験変数

\begin{tabular}{|c|c|c|c|c|c|c|}
\hline 試験体名称 & 鋼管種類 & $\mathrm{W} / \mathrm{C}$ & $\begin{array}{c}\text { 設計基準強度 } \\
\mathrm{N} / \mathrm{mm}^{2}\end{array}$ & $\begin{array}{c}\text { 開口径 } \\
\text { mm }\end{array}$ & $\begin{array}{l}\text { 吐出量 } \\
\mathrm{m}^{3} / \mathrm{h}\end{array}$ & $\begin{array}{c}\text { 配管長 } \\
\text { m }\end{array}$ \\
\hline $45-53 \mathrm{~S}$ & 450 & 53 & 27 & 150 & 10 & 120 \\
\hline $45-40 \mathrm{~F}$ & 450 & 40 & 42 & 150 & 10 & 120 \\
\hline $45-29 \mathrm{~F}$ & 450 & 29 & 60 & 150 & 10 & 120 \\
\hline $75-53 \mathrm{~S}$ & $\square 750$ & 53 & 27 & 250 & 30 & 120 \\
\hline $75-40 \mathrm{~F}$ & $\square 750$ & 40 & 42 & 250 & 30 & 120 \\
\hline $75-35 \mathrm{~F}$ & $\square 750$ & 35 & $\overline{48}$ & 250 & 30 & 120 \\
\hline $75-29 \mathrm{~F}$ & 7750 & 29 & 60 & 250 & 30 & 120 \\
\hline $75-29 \mathrm{SF}$ & 7750 & 29 & 60 & 250 & 30 & 120 \\
\hline
\end{tabular}

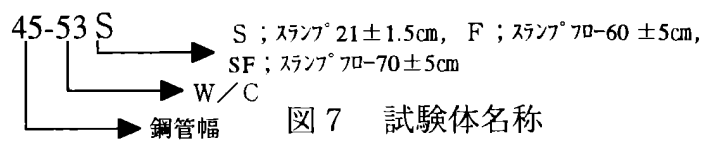


$\mathrm{mm}^{2}, \mathrm{~W} / \mathrm{C}=53 \%$ の目標スランプ $\left.21 \pm 1.5 \mathrm{~cm}\right)$ ，高流動コンクリート （設計基準強度 $42 \mathrm{~N} / \mathrm{mm}^{2} ， W / \mathrm{C}=40 \%$, 設計基準強度 $48 \mathrm{~N} / \mathrm{mm}^{2}, \mathrm{~W} / \mathrm{C}$ $=35 \%$ および設計基準強度 $60 \mathrm{~N} / \mathrm{mm}^{2}, \mathrm{~W} / \mathrm{C}=29 \%$ の目標スランプフ

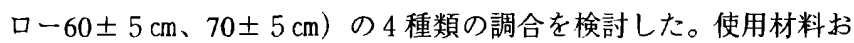
よびコンクリート調合を表 2 に示す。

\section{（3）試験体の形状および寸法}

試験体の形状および寸法を図 8 に示す。 $\square-750 \times 750 \times 28$ の試験 体ではダイアフラムの開口径を $250 \phi$ (開口率 $10 \%) 、 \square-450 \times 450$ $\times 19$ の試験体では開口径 $150 \phi （$ 開口率10\%）とし、30申の空気孔 を四隅に開けている。ダイアフラムは、一試験体当たり 6 カ所設置 し、ダイアフラムの間隔は試験体により異なる。CFTの圧入口は鋼 管内にベント管を設け、コンクリートが鋼管内で噴き上がるように した。施工実験の状況を写真 1 に示す。

(4) ポンプ配管

ポンプ配管計画を図 9 に示す。輸送管は1 $25 \mathrm{~A}$ 管を使用し、水平 部が約 $100 \mathrm{~m}$ ，鉛直部が $2 \mathrm{~m}$ とし、先端はフレキシブルホース $3 \mathrm{~m}$ に、調整管扔よび逆流止め装置を介して鋼管柱の圧入口に接続して いる。配管には各所に圧力七ンサー（フランジ式）を12力所で取付 け、管内圧力を計測した。コンクリートポンプ車はIPG1 15B-8E26/4 を使用し、最大吐出量 $115 \mathrm{~m}^{3} / \mathrm{h}$ 、最大理論吐出圧力7.1 MPa $(71.8 \mathrm{~kg}$ / caí)である。

\section{(5) 压送・压入方法}

実験作業の流れを図10に示す。コンクリートは、生コンプラン 卜に扔いて強制 2 軸ミキサを用いて製造し、現場まで運搬した。運 搬時間は10〜30分程度である。圧送開始時に、先送りモルタル 0.5 $\mathrm{m}^{3}$ ネッパに投入し、筒先で安定したコンクリートが目視によって 確認できるまでコンクリートを破棄した後に、鋼管柱内に圧入し た。コンクリートの圧送速度は鋼管内を $1 \mathrm{~m} / \mathrm{min}$ 以下で充填できる 速度とし、 $\square 750 \times 750 \times 28$ では吐出量を $30 \mathrm{~m}^{3} / \mathrm{h} 、 \square 450 \times 450 \times 19$ で は $10 \mathrm{~m}^{3} / \mathrm{h}$ に設定した。鋼管内にコンクリートを充填させた後に、コ ンクリート逆流止め装置で圧入口を止めた。

\section{2 試験項目}

試験項目および方法を表 3 にまとめて示しており、その詳細は以 下のようである。

(1) フレッシュコンクリートの品質

フレッシュコンクリートの品質試験は出荷時, 荷卸時, 鋼管圧入
ロ（筒先）および鍓管天端から採取したコンクリートをスランプ， スランブフロー, 空気量およびコンクリート温度について行った。

（2）コンクリート圧縮強度

コンクリート压縮強度は、管理用供試体（標準養生、材龄 7,28 日）として、出荷時, 荷卸時, 筒先および鋼管天端とし、構造体コ ンクリートとして（材龄28日）コア供試体を、柱断面に対して垂直 方向から 1 試験体につき、最大で12本採取した。

(3) ダイアフラム下面の充填状況

ダイアフラム下面の充填状況は、柱梁接合部を柱軸方向にダイヤ モンドカッターで切断し、ダイアフラム下面とコンクリートとの隙

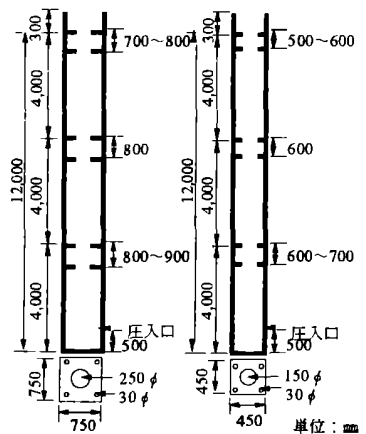

図 8 試験体形状

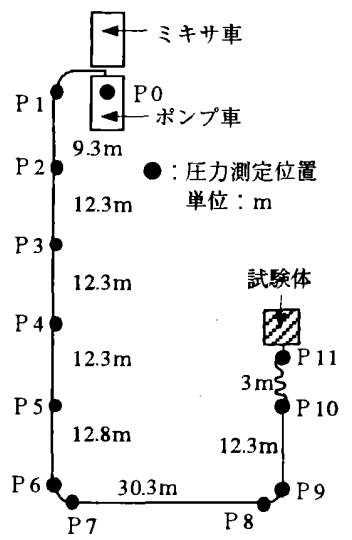

図 9 ポンプ配管

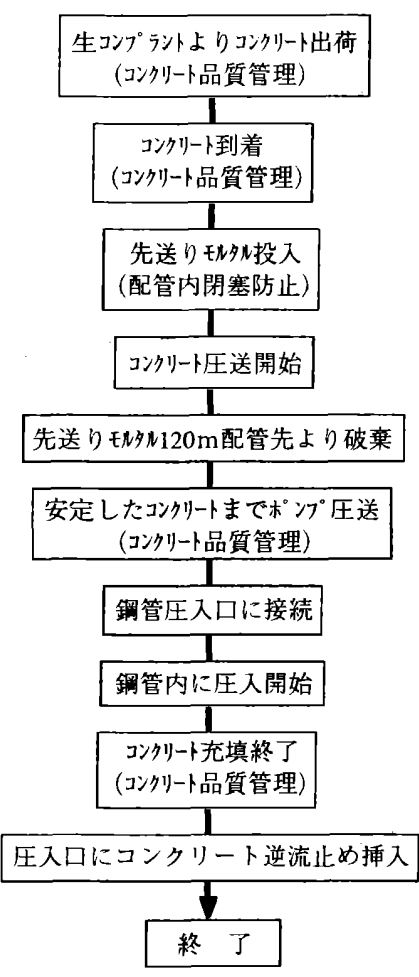

図 10 実験作業

表 2 コンクリート調合

\begin{tabular}{|c|c|c|c|c|c|c|c|c|c|c|c|}
\hline \multirow[b]{2}{*}{ 番号 } & \multirow{2}{*}{$\begin{array}{c}\text { 粗骨材の } \\
\text { 最大寸法 } \\
(\mathrm{mm})\end{array}$} & \multirow{2}{*}{$\begin{array}{l}\text { 目 標 } \\
\text { スランプ 70- } \\
(\mathrm{cm})\end{array}$} & \multirow{2}{*}{$\begin{array}{l}\text { 目 標 } \\
\text { 空気量 } \\
\text { (\%) }\end{array}$} & \multirow{2}{*}{$\begin{array}{l}\text { 水セメ } \\
\text { ント比 } \\
(\%)\end{array}$} & \multirow{2}{*}{$\begin{array}{c}\text { 細骨材 } \\
\text { 率 } \\
(\%) \\
\end{array}$} & \multicolumn{4}{|c|}{ 単 位 量 $\left(\mathrm{kg} / \mathrm{m}^{3}\right)$} & \multirow{2}{*}{$\begin{array}{c}\text { 高性能AE } \\
\text { 減水郕量 } \\
(\mathrm{C} \times \%)\end{array}$} & \multirow{2}{*}{$\begin{array}{l}\text { 分離低減 } \\
\text { 剂 量 } \\
(\mathrm{W} \times \%)\end{array}$} \\
\hline & & & & & & $\begin{array}{l}\text { 水 } \\
\mathrm{W}\end{array}$ & $\begin{array}{c}\text { 七メント }^{* 1} \\
\mathrm{C}\end{array}$ & $\begin{array}{c}\text { 細骨材 }^{* 2} \\
\mathrm{~S}\end{array}$ & $\begin{array}{c}\text { 粗骨材 }{ }^{* 3} \\
\text { G }\end{array}$ & & \\
\hline A & 20 & $21^{* 6}$ & 4.5 & 53 & 50.1 & 180 & 340 & 861 & 886 & 0.9 & 0.2 \\
\hline $\mathrm{B}$ & 20 & 60 & 4.5 & 40 & 52.2 & 170 & 425 & 880 & 819 & 1.7 & 0.15 \\
\hline C & 20 & 60 & 4.5 & 35 & 50.7 & 170 & 486 & 827 & 819 & 1.3 & 0.1 \\
\hline $\mathrm{D}$ & 20 & 60,70 & 4.5 & 29 & 48.0 & 170 & 586 & 741 & 819 & 1.1 & 0.1 \\
\hline
\end{tabular}

*1; セメント：高炉セメントB種,比重 $3.04, * 2$; 細骨材：砕砂：細砂 $=8: 2$, 表乾比重 2.61 ,吸水率 $1.33 \%$,粗粒率 $2.75, * 3$; 粗骨材: 最大寸法砕石 $20 \mathrm{~mm}$, 表乾比重 2.66 , 吸水率 $0.583 \%$,粗粒率 $6.75, * 4$; 混和都: 高性能AE減水郕 「ポリカルボン酸系」，*5; 分離低隇郕：微生物系, *6; スランプ $(\mathrm{cm})$

表 3 試験項目㧍よび試験方法

\begin{tabular}{|c|c|c|c|c|c|c|}
\hline \multirow[b]{2}{*}{ 試 } & \multirow[b]{2}{*}{ 験 項 目 } & \multirow[b]{2}{*}{ 試験方法 } & \multicolumn{2}{|c|}{ 試 } & \multicolumn{2}{|c|}{ 所 } \\
\hline & & & \begin{tabular}{|c|} 
出荷時 \\
(プラント)
\end{tabular} & 荷卸時 & $\begin{array}{l}\text { 筒 先 } \\
\text { (圧入前) }\end{array}$ & \begin{tabular}{|c|} 
鋼管天端 \\
(圧入後)
\end{tabular} \\
\hline \multirow{4}{*}{ コンクリートの品質 } & スランプ & JIS A 1101 & 0 & 0 & 0 & 0 \\
\hline & スランプフロー & JAS5 T-503 & $\mathrm{O}$ & 0 & 0 & 0 \\
\hline & 空気量 & JIS A 1128 & O & O & 0 & 0 \\
\hline & コンクリート温度 & 温度計 & 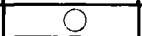 & $\mathrm{O}$ & $\bar{O}$ & 0 \\
\hline \multirow{2}{*}{ ロンクリート強度 } & 標準水中養生 & JIS A 1108 & O & $\mathrm{O}$ & $\mathrm{O}$ & $\tilde{O}$ \\
\hline & כア強度 & JIS A 1132 & - & - & - & 0 \\
\hline ヨンクリートの充瑱状況 & ダイアフラム下面の空陌 & - & - & - & - & 0 \\
\hline 施 I 性 & 压送·压入負荷 & & 圧送臬 & 始から & 主入終了” & \\
\hline
\end{tabular}

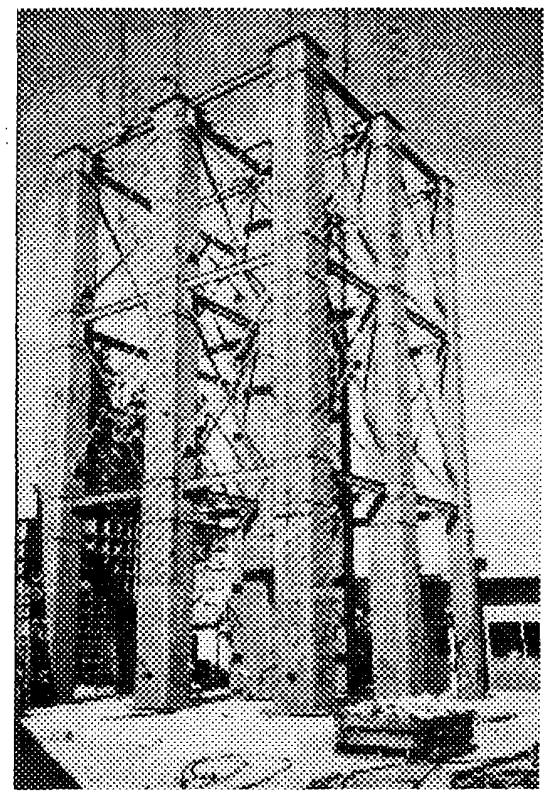

写真 1 施工実験の状況 
間を目視により確認した。

(4) 管内圧力

コンクリートの種類によるコンクリートの压入性を調べるため に、管内に設置した。圧力センサーにより計測を行った。

\section{4. 実験結果および考察}

\section{(1) 充填状況}

コンクリート圧入後の各試験体のコンクリート充填状況を図 11 に示す。試験体45-53 S は、8 m付近の位置にある2 層目のダイア フラムの上部で閉塞し、コンクリートの圧入が不可能となった。試 験体45-40F と75-53 S は、2 層目のダイアフラムを通過したが9.5m の位置で閉塞し、コンクリートの圧入が不可能となった。その他の 試験体は 3 層、 $12 \mathrm{~m}$ までコンクリートの圧入が可能であ?た。

（2）水セメント比と圧入高さ

図 11 の充填状況の結果より、鋼管幅450の試験体で圧入高さに 変化が見られた。水セメント比の小さい方が圧入高さが高くなり、 水七メント比が大きい方が鋼管の途中で閉塞する傾向にあった。鋼 管幅7 50 の試験体からも同様の結果が見られた。これは、コンク リートの単位セメント量の影響によるものと考えられる。

\section{（3）コンクリートの品質}

コンクリートの品質試験の結果を表 4 に示す。スランプあるいは スランプフローは、出荷時に比べて、筒先ではほとんど低下が見ら れなかったが、鋼管天端では、スランプフローが最大で $18 \mathrm{~cm}$ 、平均 で $4 \mathrm{~cm}$ 低下した。筒先でスランプフローの低下が少ないのは、先送 りモルタルが配管内に付着しているためであり、鋼管天端でスラン プフローの低下が見られるのは、充填するコンクリートのモルタル が鋼管柱の側面に付着したためと考えられる。空気量は、出荷時に 比べて鋼管天端で若干増加する傾向にあるが、顕著ではなかった。 鋼管圧入において、水セメント比が大きい方が閉塞したことを考慮 すると、水セメント比が小さく、粉体が多い方が充填性が良好であ ることがわかった。

\section{(4) コンクリート圧縮強度}

管理用供試体の結果を表 5 に示す。管理用供試体は28日で設計基 準強度を満足していた。コア供試体の採取位置と圧縮強度比を図 12
に示す。压縮強度比は、鋼管の一番上で採取したコア供試体の圧縮 強度を基準として、各箇所の強度比を求めている。コア供試体は管 理用供試体より $5 \%$ 程度低い強度となった。各試験体とも鋼管下部 での強度比が高くなっているが、これは、鋼管下部ほどコンクリー トの自重が大きくなり、コンクリートが密実に硬化するためと考え られる。また、ダイアフラム前後で強度比にばらつきが生じてい た。これは、コンクリートがダイアフラムを通過する際に影響を受 けるためだと考えられる。また、水セメント比が小さいほどコンク リート压縮強度のばらつきが少なかった。

（5）コンクリートの品質管理

杮崎他6) の研究によると、本実験の45-53 F と同程度の調合で $\square-$ $600 \times 600 \times 19$ で高さ $19.4 \mathrm{~m}$ の圧入に成功した報告がされている。こ

表 4 （a）スランプ，スランプフロー

\begin{tabular}{|c|c|c|c|c|}
\hline 試験体名称 & $\begin{array}{c}\text { 出荷時 } \\
\mathrm{cm} \times \mathrm{cm}\end{array}$ & $\begin{array}{c}\text { 荷卸時 } \\
\mathrm{cm} \times \mathrm{cm}\end{array}$ & $\begin{array}{c}\text { 筒 先 } \\
\mathrm{cm} \times \mathrm{cm}\end{array}$ & $\begin{array}{c}\text { 鋼管天端 } \\
\mathrm{cm} \times \mathrm{cm}\end{array}$ \\
\hline $45-53 \mathrm{~S}$ & 21.5 & 20.5 & 20.5 & - \\
\hline $45-40 \mathrm{~F}$ & $66 \times 64$ & $59 \times 56$ & $55 \times 55$ & - \\
\hline $45-29 \mathrm{~F}$ & $68 \times 65$ & $58 \times 55$ & $55 \times 54$ & $47 \times 46$ \\
\hline $75-53 \mathrm{~S}$ & 22.5 & 20.5 & 19.5 & - \\
\hline $75-40 \mathrm{~F}$ & $60 \times 58$ & $63 \times 60$ & $64 \times 61$ & $58 \times 58$ \\
\hline $75-35 \mathrm{~F}$ & $66 \times 66$ & $61 \times 60$ & $58 \times 58$ & $60 \times 60$ \\
\hline $75-29 \mathrm{~F}$ & $57 \times 57$ & $63 \times 61$ & $58 \times 56$ & $45 \times 46$ \\
\hline $75-29 \mathrm{SF}$ & $70 \times 68$ & $63 \times 65$ & $70 \times 69$ & $69 \times 68$ \\
\hline
\end{tabular}

表 4 （b）空気量

\begin{tabular}{|c|c|c|c|c|}
\hline 試験体名称 & $\begin{array}{c}\text { 出荷時 } \\
\%\end{array}$ & $\begin{array}{c}\text { 荷卸時 } \\
\%\end{array}$ & $\begin{array}{c}\text { 筒 } \\
\%\end{array}$ & $\begin{array}{c}\text { 先 } \\
\text { 鋼管天端 } \\
\%\end{array}$ \\
\hline $45-53 \mathrm{~S}$ & 5.6 & 3.4 & 4.3 & - \\
\hline $45-40 \mathrm{~F}$ & 7.2 & 6.5 & 6.6 & - \\
\hline $45-29 \mathrm{~F}$ & 6.2 & 3.7 & 6.2 & 4.9 \\
\hline $75-53 \mathrm{~S}$ & 3.6 & 3.4 & 3.1 & - \\
\hline $75-40 \mathrm{~F}$ & 3.5 & 4.1 & 3.8 & 4.0 \\
\hline $75-35 \mathrm{~F}$ & 5.5 & 5.5 & 5.5 & 5.0 \\
\hline $75-29 \mathrm{~F}$ & 4.0 & 4.1 & 4.7 & 5.1 \\
\hline $75-29 \mathrm{SF}$ & 6.3 & 6.0 & 6.2 & 6.4 \\
\hline
\end{tabular}

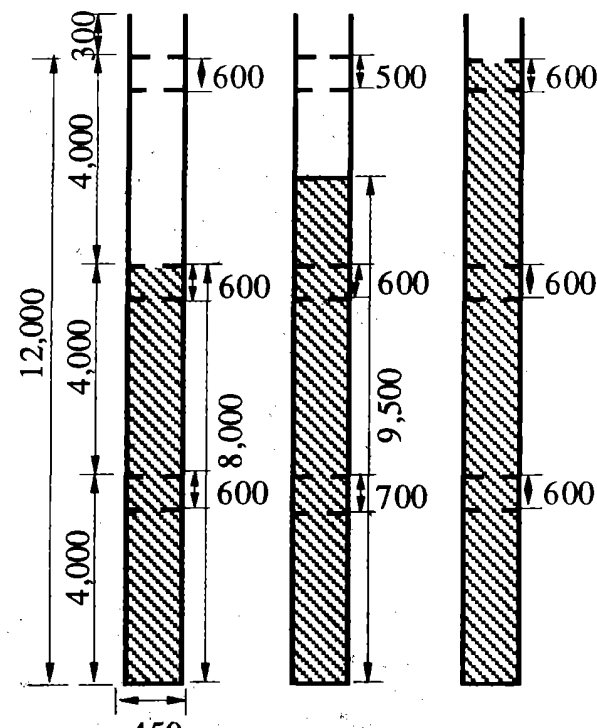

450

45-53 S $\quad 45-40 F \quad 45-29 F$

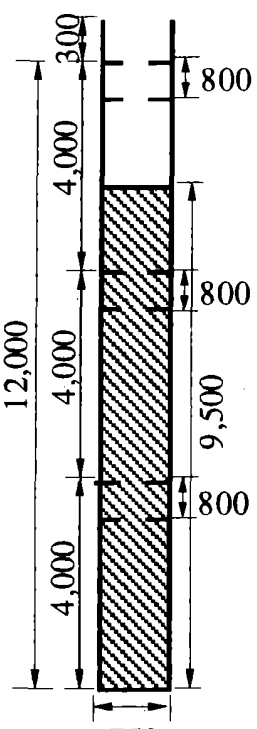

750
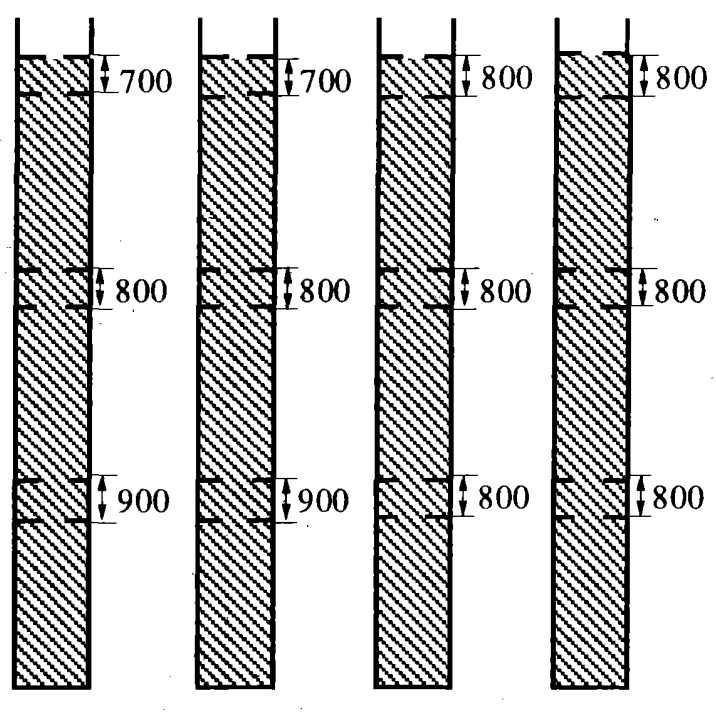

$75-53 \mathrm{~S}$
$75-40 \mathrm{~F}$

\section{5-35 F 75-29F 75-29SF \\ \#: コンクリート充填を示す}

図 11 コンクリート充填状況 
の文献によるとコンクリートのスランプフローの管理值を荷卸し時

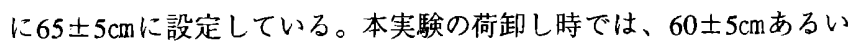

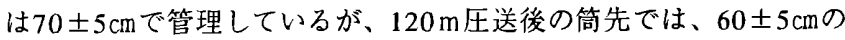
下限値約 $55 \mathrm{~cm}$ まで低下していた。スランプフローが55cmまで低下し ていた試験体は、閉塞あるいは鋼管天端でスランプフローの低下が 大きかった。筒先で $60 \mathrm{~cm} あ る い 70 \mathrm{~cm} に$ 近い試験体は、鋼管天端に おいてもスランプフローの低下があまり見られなかった。したがっ て、圧入前のスランプフローの管理値を $60 \mathrm{~cm}$ 以上に設定することに よって、コンクリートの充填性が向上すると考えられる。

また、45-40Fと45-29Fの筒先のスランプフローが同じであった が、鋼管圧入に差が生じたことから、水セメント比の小さい方が充 填性が有ることがこのことからも言える。

（6）圧送·圧入負荷

配管距離と管内圧力との関係を図 13 に示す。管内圧力は、ポン プ車に近いほど圧力が大きくなる結果となった。また、吐出量10、 $30 \mathrm{~m}^{3} / \mathrm{h}$ ともに水セメント比が小さいほど管内压力が高い傾向にあっ た。これは、コンクリートの単位セメント量などによろ粘性の影響 と考えられ、コンクリートの調合の違いによる圧送、压入負荷の検 討も必要と考えられる。

（7）開口面積とコンクリートの立填性

高流動コンクリートを用いた鋼管寸法7500試験体では、コンク リートを十分に充填することができ、コンクリートの品質変化およ び強度比のばらつきも小さくCFTに充填するコンクリートとして適 していると考えられる。しかし、試験体45-40 F は、高流動コンク リートであるが、 $9.5 \mathrm{~m}$ の時点で閉塞した。これは、ダイアフラム の開口面積率は10\%で同じであるが、鋼管寸法 450 の試験体は、ダ

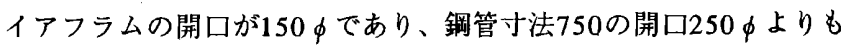
面積が小さいためと考えられる。また、同じ高流動コンクリートで も試験体45-29 F は圧入できたことから、コンクリートの単位セメ ント量の影響による銅管柱の圧入時に生じる摩擦抵抗などが考えら れる。さらに、普通コンクリートの試験体45-53 Sおよび75-53 Sで も開口面積によって充填高さが変わっていた。このことから、同じ $10 \%$ の開口面積率で、同じ調合の試験体にもかかわらず、充填高さ が変わっていることから、CFTの充填性は開口面積率に必ずしも依 存していないと思われる。したがって、ダイアフラムの開口面積率 を技術指針2)で示されている15\%を確保することで、CFTへの充填 性が確定されるのではなく、コンクリートの充填性は、鋼管の規模 による必要最低限の開口面積の大きさが必要であり、両者には密接 な関係があると考えられる。さらに、充填された試験体において も、この開口面禎による圧入可能な高さが予想され、開口面積と圧
入高さとの関係も、開口面積とコンクリートの充填性同様に検討が 必要であると考えられる。

\section{表 5 コンクリート圧縮強度}

\begin{tabular}{|c|c|c|c|c|}
\hline 試験体名称 & $\begin{array}{c}\text { 出荷時 } \\
\mathrm{N} / \mathrm{mm}^{2}\end{array}$ & $\begin{array}{c}\text { 荷卸時 } \\
\mathrm{N} / \mathrm{mm}^{2}\end{array}$ & $\begin{array}{c}\text { 筒 先 } \\
\mathrm{N} / \mathrm{mm}^{2}\end{array}$ & $\begin{array}{c}\text { 鋼管天端 } \\
\mathrm{N} / \mathrm{mm}^{2}\end{array}$ \\
\hline $45-53 \mathrm{~S}$ & 32.4 & 34.2 & 36.6 & - \\
\hline $45-40 \mathrm{~F}$ & 44.6 & 46.1 & 48.6 & - \\
\hline $45-29 \mathrm{~F}$ & 67.0 & 66.4 & 65.2 & 68.7 \\
\hline $75-53 \mathrm{~S}$ & 36.8 & 38.8 & 38.1 & - \\
\hline $75-40 \mathrm{~F}$ & 44.2 & 45.6 & 45.0 & 49.4 \\
\hline $75-35 \mathrm{~F}$ & 56.4 & 52.8 & 58.6 & 58.6 \\
\hline $75-29 \mathrm{~F}$ & 72.0 & 76.4 & 75.8 & 63.9 \\
\hline $75-29 \mathrm{SF}$ & 66.3 & 69.6 & 64.0 & 69.1 \\
\hline
\end{tabular}
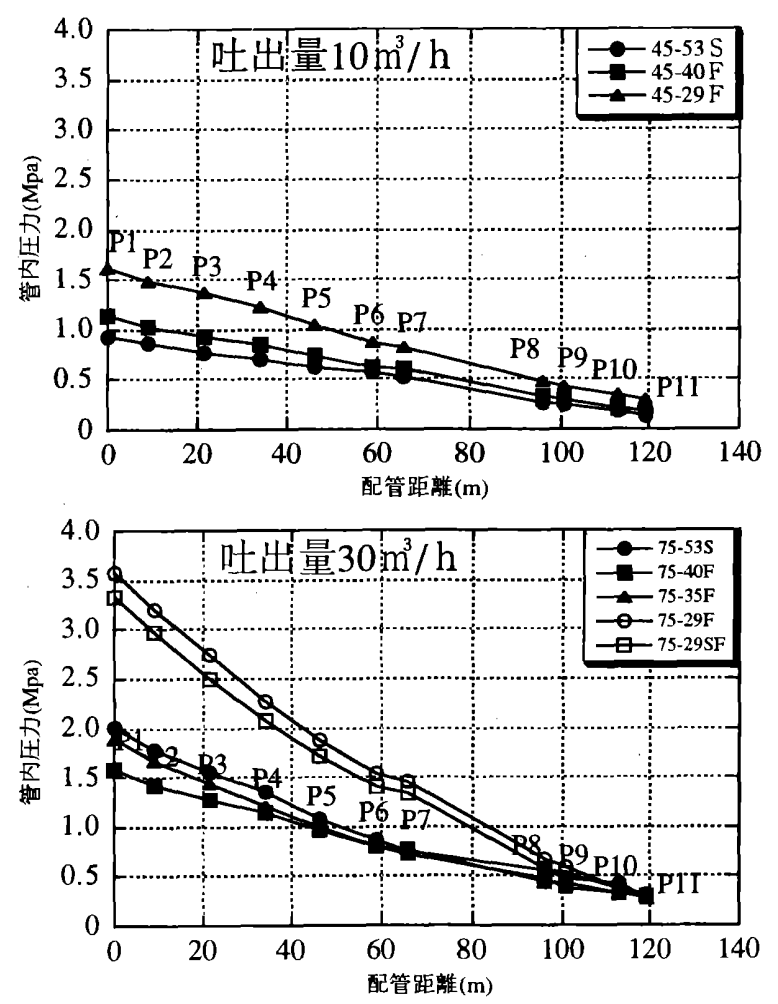

図 13 配管距離と管内圧力

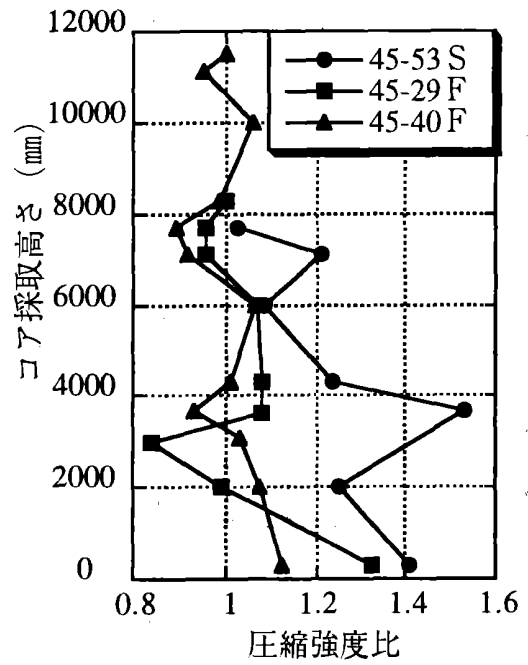

圧綟強度比
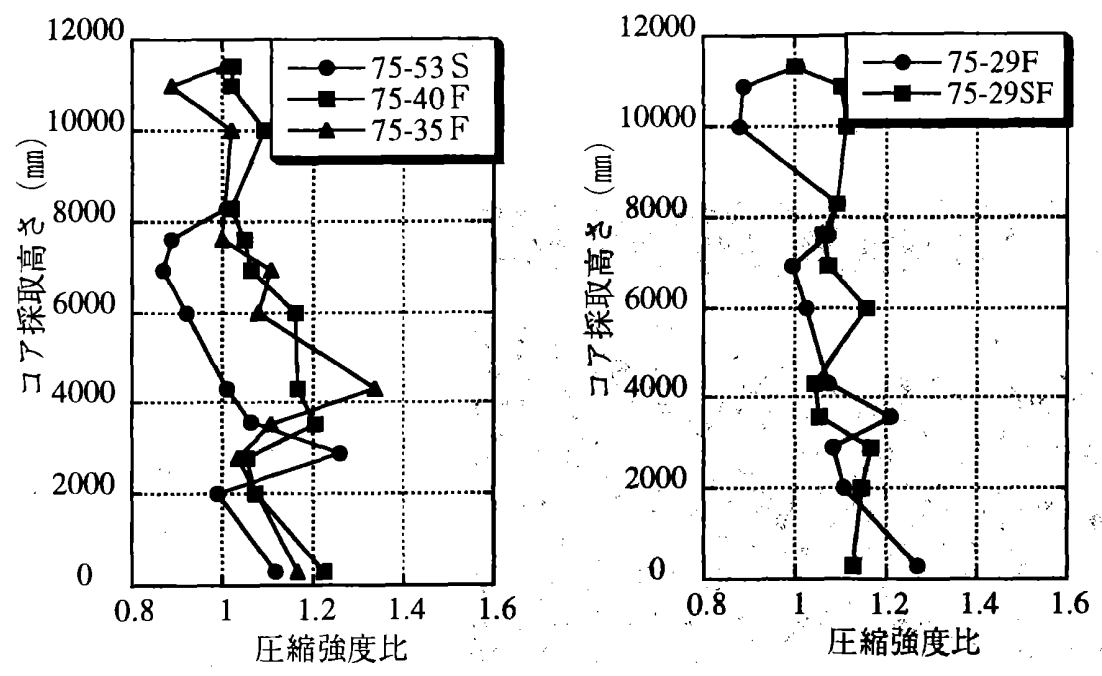

図 12 コンクリート圧縮強度比 
（8）ダイアフラム下面の充填状況

ダイアフラム下面のコンクリート充填状況を写真2 に示す（試験 体75-29Fの 1 層目）。ほとんどの試験体でダイアフラム下面の沈降 は見られず、十分に充填されていることがわかった。また、鋼管柱 脚部の方が、上層部より若干の沈降する傾向があったが、これはコ ンクリートの自重による影響であると考えられる。

\section{（9）圧入高さへの影響}

本実験の結果を各種コンクリートと圧入高さに及ほす影響に ついてまとめると、スランプフローー鋼管圧入高さの関係を図 14に、水セメント比一鋼管圧入高さとの関係を図15に示す。

また、既往の文献についてもそれぞれの関係を図16、図17に 示した。ただし、既往の文献は、スランプフロー、水セメント 比を 10 刻みで分類し、鋼管圧入高さとの関係を示した。な お、その分類した範用の最大、最小値の範囲を示し、メ印はそ の範囲での平均圧入高导を示している。なお、W/C = 20 30末 満では、60 mの値のみであったので最大値のみを表示し、最小 値、平均値䏡していない。

まず、図14より、スランプフロー $55 \mathrm{~cm}$ 前後で圧入可能領域の 境となり、鋼管内にコンクリートを圧入するには高流動コンク リートが不可欠なことがわかった。さらに、図16において、圧 入高さの最大值にばらつきはあるが、スランプフローが $55 \mathrm{~cm}$ よ り大きい方が圧入高さの平均值も上昇している。また、4 0 〜 $50 \mathrm{~cm}$ 未満において、平均压入高さが $20 \mathrm{~m}$ 程度であった。鋼管の ダイアフラムの開口率に差があるため一概には言えないが、ス ランプフローが $50 \mathrm{~cm}$ 程度の場合、圧入高さが $20 \mathrm{~m}$ 程度が限界に 近いことがわかり、本実験の開口率が $10 \%$ であることを考慮す ると本実験におけるスランプフロー55 c m 以下では、限界圧入高 さが1 $2 \mathrm{~m}$ 程度である事が推測できる。したがって、圧入高さが $12 \mathrm{~m}$ 以上要求される場合には、压入口でのスランプフローが $55 \mathrm{~cm}$ 以上必要であり、開口面積率も $15 \%$ 以上必要であると考え られる。

次に、図15に関しても、スランプフローと同様の考え方をす ると、水セメント比4 0 \% で圧入可能領域の境であると考えられ る。図 17 においても、水セメント比 $40 \sim 50 \%$ 未満での圧入高さ が $20 \mathrm{~m}$ 未満であることから、圧入高さが $12 \mathrm{~m}$ 以上要求される場合 には、水セメント比が少なくとも 40 \%以下になるようなコンク リートの調合設計が必要であると思われる。

\section{5.まとめ}

今回行った、圧入施工実験により得られた結果を以下に示す。 各種コンクリートと圧入高さの関倸は、

（1）コンクリートの圧入高さはスランプフローの影響が大きく、 スランプフローが大きい方が圧入高さが高くなり、スランプフロー $55 \mathrm{~cm}$ 以下では $12 \mathrm{~m}$ 程度の圧入高さしか得られなかった。

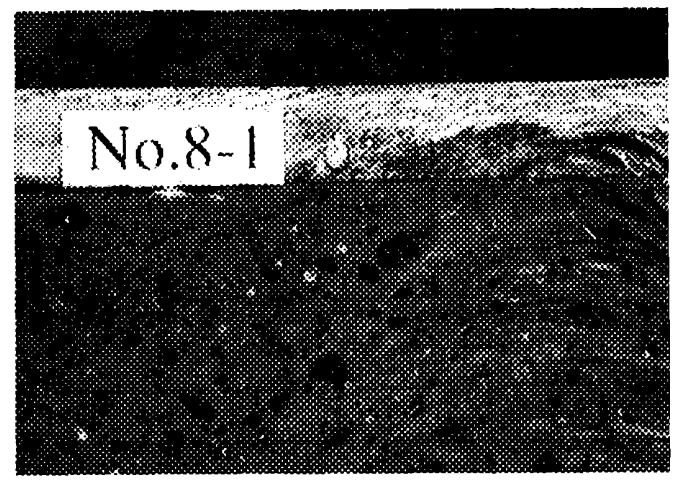

写真 2 コンクリートの充填状況

（2）コンクリートの圧入高さは水セメント比にも影響を受け、水 セメント比が低い方が圧入高さが高くなり、水セメント比 $40 \%$ 以上 では、12m程度の圧入高さしか得られなかった。

（3）ダイアフラムの開口面積率が同じ場合でも、鋼管内で閉塞し たことから、鋼管断面に対する必要最低限の開口面積が存在してい ると考えられる。

次に、充填コンクリートに関しては、

（4）コンクリートの品質変化は、水平配管での圧送ではほとんど 見られず、鋼管圧入によって若干スランプフローが低下する傾向で あった。

（5）鋼管压入前のコンクリートスランプフローを $60 \mathrm{~cm}$ 以上で管理 することによって、充填性をより向上することができる。

（6）充填されたコンクリートの圧縮強度は、下層ほど大きくなる 傾向にあり、ダイアフラムの前後で少し強度のばらつきがみられ た。水セメント比が小さい方が強度のばらつきが少なかった。

（7）コンクリートの充填は、高流動コンクリートを用いた場合、 水セメント比の値が小さいほど充填性がよく、ほとんど空䏚なく充 填することができた。

CFTのコンクリートの充填性は、スランプフロー、水セメント比 によって鋼管圧入高さ、コンクリート品質および圧縮強度など大き く影響を受け、水セメント比が低い高流動コンクリートほどCFTに 適していることがわかった。

今後さらに各種コンクリートと压入高さの関係について検討して いきたい。

【参考文献】

1) コンクリート充填鐝管構造設計施工指針，日本建築学会 2）CFT棈造技術指針・同解 説，仕新都市ハウジング協会pp.75，1997 3）文献調查から見たCFTの施工技術とその動 向，建等技術第 568号，pp.208２13，1997.7 4) 岩沢，中田他：コンクリートボンプに よるCFT (コンクリート克填鋼管柱) の圧入工法に関する文献調査, 日本大学生産工学 部第29回学術講演会建等部会, pp.43〜46, 1996 5) 岩沢, 中田他：高流動コンクリート を用いたコンクリート充填鋼管柱の圧入施工実験，コンクリート工学年次論文報告集 Vol.19,No.1，pp.109－114，1997 6）柿崎他：地下駅工事の无填銅管柱への高流動コンク リート压入施工；日本建栄学会技術報告集，第 5 号，pp.1 6，1997.12 7) コンクリート ボンプ工法施工指針・同解説, 日本建築学会, 1994

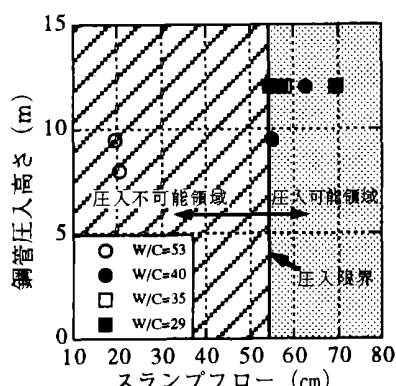

図 14 スランプフロー 一 鋼管圧入領域

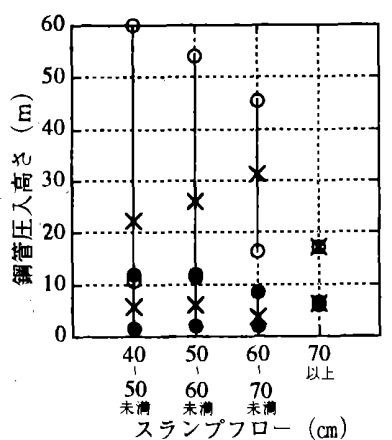

図 16 スランプフロー 一 鋼管圧入範囲

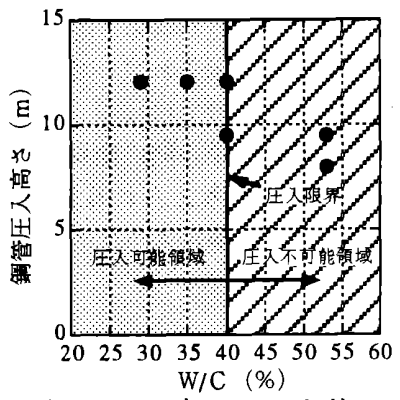

図 15 水セメント比 一鋼管圧入領域

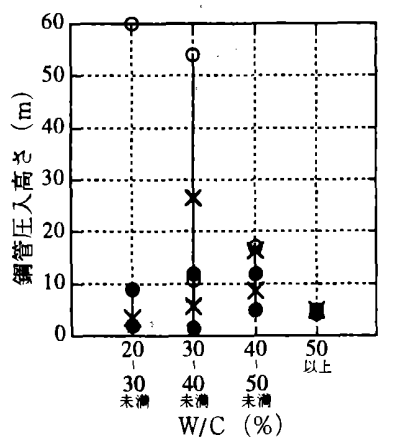

図 17 水セメント比 一 鋼管圧入範囲 